\title{
KÉSZTERMÉKEK KEZELÉSEINEK OPTIMÁLHATÓSÁGI VIZSGÁLATA
}

\author{
Juhász János \\ doktorandusz, Miskolci Egyetem, Logisztikai Intézet \\ 3515 Miskolc, Miskolc-Egyetemváros,e-mail: juhaszj@uni-miskolc.hu
}

\begin{abstract}
Absztrakt
Jelen cikkem a Logisztika 4.0 prosperáló hatására a belső vállalati logisztikai folyamatokkal foglalkozik, hiszen a teljes ellátási lánc eredményes és korszerü fenntartása kiemelt logisztikai feladat. A kutatásom egy fiktív bázisvállalat késztermékeinek kiszerelési tevékenységeit elemzi annak érdekében, hogy a folyamatok intenzifikálhatóak legyenek. Kiemelten foglalkozom a lehetséges egységrakományképzési, csomagolási, tárolási és árukiadási folyamatokkal, valamint ezek kapacitásaival. A cikk célja az, hogy alternatív megoldásokat mutassak be az árukiadás belső folyamatainak áteresztö képességének javitására és az azonositott szük keresztmetszetek feloldására. A bemutatott matematikai modell segitségével lehetôvé válik a meglévő erőforrások optimális allokációja a jelenlegi logisztikai terület hatékony üzemeltetésére.
\end{abstract}

Kulcsszavak: Logisztika 4.0, ellátási lánc menedzsment, vevőkiszolgálás fejlesztés, optimalizálás

\section{Abstract}

My article deals with the internal companies' logistics processes in the prosperous effect of Logistic 4.0, because the effective and up-to-date company' sustainment is a key logistic task. My research analyzes the fictitious base company' finished product packaging activities in order to intensify the processes. I have focused for the typical forms of unit load, packaging, storage and its capacities. The aim of this paper is to find alternative solutions to improve the permeability of the stock release internal processes and resolve the identified bottlenecks. The presented mathematical model allows the optimal allocation of our resources for the efficient operation in the current logistics operation.

Keywords: Logistic 4.0, supply chain management, development of customer service, optimization

\section{Bevezetés}

A vállalatok az anyagáramlási folyamatok segítségével juttatják el késztermékeiket a végfelhasználóinak oly módon, hogy minél hatékonyabban és a lehető legrövidebb átfutási idő alatt hajtsák ezeket végre. A hatékonyság elérése az anyagáramlási rendszer termelö folyamatainak elemzésein alapul, hiszen általános esetben bonyolultabb, mint a szolgáltatások anyagáramlási rendszere [1]. A logisztika az anyagforrásoktól a vevőhöz juttatásig terjedő fizikai áramlásának szervezésével és irányításával (koordinálásával) foglalkozik [2].

A termelöüzemek végtermékeit a logisztikai feladatokat ellátó szolgáltatók kezelik le, melyek főbb feladata, hogy előkészítsék a kiszállításokat a vevő által igényelt termékkel. Tehát egy stabil müködésủ és gazdaságos kiszerelési folyamatlánc létrehozására van szükség, mely összhangban van a vevők által meghatározott megrendelések teljesítésének időpontjával. 
A logisztikai tevékenységek feltérképezésével meghatározhatóak a működésből adódó szűk keresztmetszetek, melyek segítségével láthatóvá és javíthatóvá válik a már müködő jelenlegi rendszer hatékonysága. A szük keresztmetszetek definiálásának egyik módszerét használom fel, azaz mélyvizsgálat történik, ahol az ellátási lánc bonyolult logisztikai folyamatai alapján a rendszert akadályozó korlátok megjeleníthetőek. Nevezetesen az adott technológia adottságából adódnak, hiszen a rendszer elöre definiált feladathalmaz ellátására képes. Azonban az említett hatékonyság növelés, a folyamatok finomhangolásával elérhetőek, melyek növelni és javítani tudják a kiszolgáló kapacitásainkat.

A bázisvállalat ebben az esetben egy erre specializálódott logisztikai szolgáltatóra bízza a logisztikai tevékenységeket az önfenntartás érdekében. Ennek hatására a vevőkiszolgálási folyamatokban megjelenik egy harmadik külső fél (3PL), azaz a vállalkozó garantálja a zökkenőmentes és folyamatosan fejlődő kiszolgálást. A 3PL szolgáltatók (Third Party Logistics System Providers) szolgáltatásai az ellátási lánc dedikált részeire terjednek ki, míg a 4PL szolgáltatók (Fourth Party Logistics System Providers), akár már a teljes ellátási lánc irányításáért és megvalósításáért is felelnek [3].

A logisztikai kiszervezést, mint szolgáltatást több logisztikai tevékenységen is érthetjük, melyek a következőek lehetnek:

1. Szállítás

2. Csomagolás

3. Szállítás-menedzsment

4. Elosztási hálózat menedzsment

A Capgemini globális vezető szerepet tölt be kiszervezési szolgáltatások területein. Az alkalmazott kiszervezések a fent említett szinteken felül a komplex logisztikai hálózat kontrolálása érthető [4].

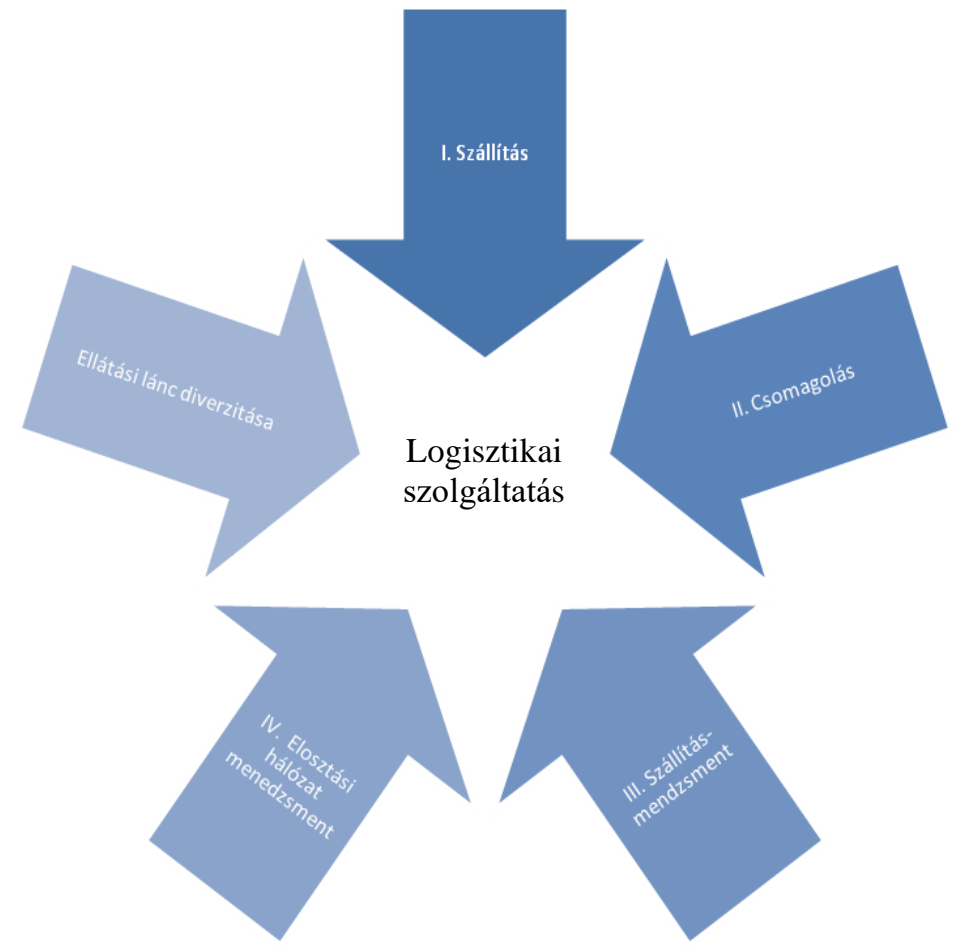

1. ábra. Logisztikai szolgáltatás értelmezése [Saját szerkesztés] 
Az 1. ábra alapján az ellátási lánc több piaci szereplö között értelmezhető, ahol a vállalatok egyes piaci adottságai jelentős hatást gyakorolnak a menedzsment folyamatokra. Elvárás a gazdaságos müködtetés a versenyképesség megörzése érdekében.

Az ellátási lánc menedzsment fogalma alapján az ellátási lánc több piaci résztvevő között értelmezhető, célja a végfelhasználó igényeinek maximális kielégítése, valamint az értékteremtés. Az ellátási láncban a résztvevő vállalatok együttesen határozzák meg a lánc piaci teljesítőképességét, az együttmüködés célja nem egy - egy vállalat helyzetének, hanem a lánc egészének optimalizálása [5].

\section{Bázisvállalat késztermék kezelési folyamatainak elemzése}

Az ellátási láncok fejlődései szorosan összefüggnek a globalizációval, a technológiával és a piaci szereplőkkel. Számos szempontrendszert vizsgál meg, mint például az általános motivációkat, az igényeket, és a kiszolgálási folyamatokat.

\subsection{Bázisvállalat ellátásának értelmezése}

A müködési költségek csökkentései lehetőséget biztosítanak kutatás-fejlesztésekhez $(\mathrm{K}+\mathrm{F})$, hiszen hosszútávon meg kell őrizni a piacon betöltött szerepet, vagy éppen az üzletág vezető pozícióját.

A rugalmasság sem elhanyagolható tényező, mivel a vevők igényeihez mérten kell kiszolgálni. A szakirodalom alapján a 2. táblázatban gyüjtöttem össze az általános motivációkat.

2. táblázat. Általános motivációk [6]

\begin{tabular}{|c|c|c|}
\hline $\begin{array}{c}\text { Költség csökken- } \\
\text { tés }\end{array}$ & $\begin{array}{c}\text { Vállalati képesség } \\
\text { fejlesztés }\end{array}$ & Bevétel növelés \\
\hline $\mathrm{K}+\mathrm{F}$ & $\begin{array}{c}\text { Jól képzett munkatár- } \\
\text { sak }\end{array}$ & Piaci szerep stabilitás \\
\hline Müködési költség & $\begin{array}{c}\text { Főtevékenységekre } \\
\text { fókuszálás }\end{array}$ & Vezető üzletág \\
\hline Beruházás (tőke) & Rugalmasság & $\begin{array}{c}\text { Minőség menedzs- } \\
\text { ment (QM) }\end{array}$ \\
\hline EÜ ellátás & Precizitás & Új piac felkutatás \\
\hline $\begin{array}{c}\text { Fix költségek el- } \\
\text { tüntetése }\end{array}$ & - & Szolgáltatás bővítés \\
\hline
\end{tabular}

Ahogyan a 2. táblázat is összefoglalja a motivációkat három föbb csoportba soroltam be: 1) a költségcsökkentés, 2) a vállalati képességek fejlesztése és 3) a bevételek növelése. Az ismertetett rendszerezés alapján fontos, hogy a vevői igényeket maximálisan kielégítő termékeket jutassunk el a megrendelöinkhez, valamint az erőforrásainkat minimalizálni, profitunkat maximalizálni tudjuk a rendszer hatékony üzemeltetésével.

\subsection{A logisztikai szolgáltatás fôbb feladatai}

A logisztikai kezelés alapja a termelővállalatok késztermékei. A bázis vállalat megköveteli a magasszintủ és folyamatosan fejlődő logisztikai szolgáltatások ellátását [7]. 
A továbbiakban összefoglalom a kutatásomhoz nélkülözhetetlen logisztikai tevékenységeket, melyek elemzései után optimálhatóak az egyes folyamatok, valamint innovatív megoldási javaslatokat dolgozhatok ki. A tanulmány során bemutatom a kiszerelési formákat és annak jellegzetes folyamatait, hiszen az egyes folyamatok fejlesztése a szük keresztmetszetek ismeretében érhetők el.

Fontos megjegyezni, hogy kiemelt figyelmet kell fordítani a tevékenységekhez kapcsolódó jogszabályokban rögzítetteknek, valamint a cég belső szabályzatainak maradéktalan betartására.

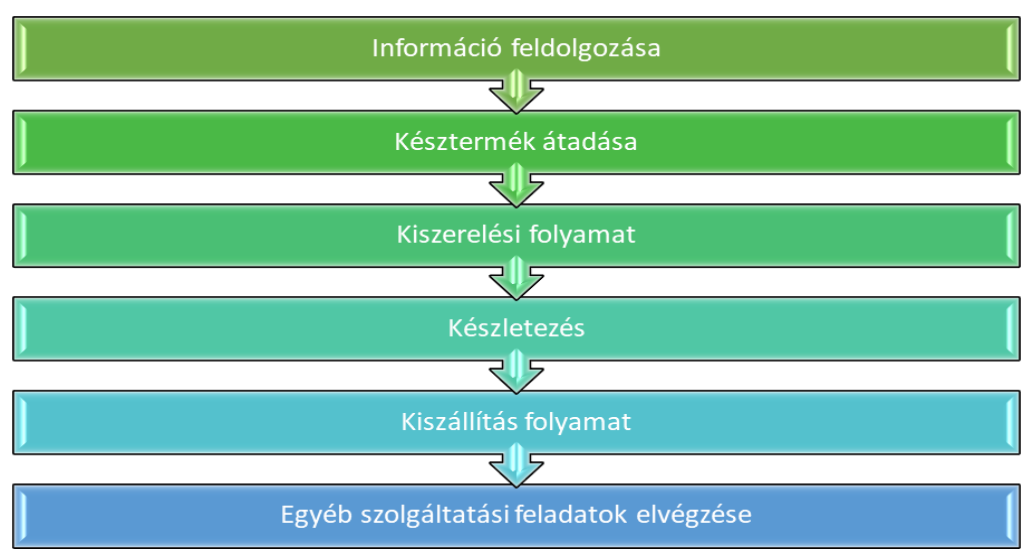

3. ábra. Késztermék kezelésének logisztikai feladatai [Saját szerkesztés]

Ahogyan a 3. ábra is reprezentálja, a logisztika tevékenység széleskörü feladata van jelen, mely kiterjed az információk feldolgozására, a késztermékek átadása, a kiszerelési folyamatokra, a készletezésre, kiszállítás folyamatainak szervezésére és egyéb dokumentálási- szolgáltatási feladatok ellátására.

4. táblázat. Kiszolgáló üzemek definiált paraméterei [Saját szerkesztés]

\begin{tabular}{|c|c|c|c|}
\hline $\begin{array}{c}\text { Kiszolgáló területi } \\
\text { logisztikai (LOG) } \\
\text { egységek }\end{array}$ & Müszak szám & $\begin{array}{c}\text { Múszakok időtar- } \\
\text { tama }\end{array}$ & $\begin{array}{c}\text { Gyártás/nap } \\
\text { [t] }\end{array}$ \\
\hline LOG 1 & 2 & $\begin{array}{c}6: 00-14: 00 \\
14: 00-22: 00\end{array}$ & 360 \\
\hline LOG 2 & 3 & $\begin{array}{c}6: 00-14: 00 \\
14: 00-22: 00 \\
22: 00-06: 00\end{array}$ & 660 \\
\hline LOG 3 & 2 & $\begin{array}{c}6: 00-14: 00 \\
14: 00-22: 00\end{array}$ & 624 \\
\hline LOG 4 & 2 & $\begin{array}{c}6: 00-14: 00 \\
14: 00-22: 00\end{array}$ & 840 \\
\hline LOG 5 & 2 & $\begin{array}{c}6: 00-14: 00 \\
14: 00-22: 00\end{array}$ & 228 \\
\hline
\end{tabular}

A 4. táblázat alapján a kiszolgáló LOG egységeket folyamatos müködés jellemzi, hiszen a termelés minden nap 24 órában történik. Munkarendjük állandó, azaz munkanapokon heti 5 nap váltott mü- 
szakrendben látnak el kiszolgáló tevékenységet. Gyakoriságuk a késztermékek mennyiségétől függ, hogy biztosítani tudják a folyamatos termékátvételt.

A következökben ismertetem a fiktív cég logisztikai sajátosságait, amiket ezután különféle elemzések útján vizsgálok. Feltételezem, hogy a vevők kiszolgálása tervszerüen történik, aminek az alapja a termelés programozás és ütemezés (PPS). A kettő között az a alapvető különbség, hogy a termelésprogramozás időegység alapú és rendezés nélküli, míg a termelésütemezés folytonos időábrázolást használ és sorrendezést készít el.

\section{Bázisvállalat logisztikai rendszerének modellezése és fejlesztése a szük keresztmetsze- teinek ismeretében}

A szakirodalom azt bizonyítja, hogy a logisztikai kiszervezések (logistic outsourcing) hátterében általában a költségcsökkentés áll, hiszen a folyamatosan megváltozó vevői igények komplex logisztikai feladatokat generálnak. A logisztikai szolgáltatóval vagy egy kooperatív CoVRP (Cooperative Vehicle Routing Problem) történő együttmüködés lehetőséget biztosit a hatékonyság és az eredményesség növelésére [8].

A piaci szereplök a folyamatos a vevői igények szerinti ellátásra törekednek. A kiszállítási feladatok ütemezései egy integrált vevőcentrikus termelésprogramozást kíván meg az alábbi ütemezési feladatoknál [9]:

- termelö sor(ok),

- kiszerelés,

- kiszállítás ütemezés.

A fiktív vállalat logisztikai tevékenysége egy komplex húzó ipari termelésre épül, melyet több különböző típusú és volumenü logisztikai egység valósít meg. A feltételezett kiszolgáló egységek tárolási formáit egy meghatározott időszakban vizsgálom, melynek alapja a rendelkezésre álló logisztikai üzemek által biztosított adatcsomagok kiértékelése.

Tehát a kiterjedt logisztikai hálózat és a keresleti csomópontok stabilabbá teszik az LPDI (Logistics providers concerned with integrated delivery and installation) és az LLP (Local Logistics Provider) közötti együttmüködési kapcsolatot, vagyis a hosszú távú együttmüködést részesítik előnyben [10].

A komplex modell rendszereket az alábbi 5. ábra mutatja be, ahol a gyártás, a kiszerelés és a szállítás kapcsolatai definiálhatóak:

LOG 1:

- R1 Közút: közúti tartálykocsitöltés, ömlesztett;

- R2 Vasút: vasúti konténeres, ömlesztett;

- R3 Közút: közúti konténeres, platós zárt jármün;

- R4 Vasút: vasúti konténeres, ömlesztett;

- R5 Közút: közúti zsákokba kiszerelve, rakodólapos zárt jármün;

- R6 Vasút: vasúti konténeres, ömlesztett;

- R7 Közút: közúti BIG-BAG zsákban raklapos, zárt járműn;

- R8 Vasút: vasúti konténeres, raklapos BIG-BAG zsákban, vasúti kocsin;

LOG2:

- R9 Közút: közúti tartálykocsitöltés, ömlesztett;

- R10 Vasút: vasúti konténeres, ömlesztett;

- R11 Közút: közúti konténeres, platós zárt jármün;

- R12 Vasút: vasúti konténeres, ömlesztett; 
- R13 Közút: közúti zsákokba kiszerelve, rakodólapos zárt jármün;

- R14 Vasút: vasúti konténeres, ömlesztett;

LOG 3:

- R15 Közút: közúti tartálykocsitöltés, ömlesztett;

- R16 Vasút: vasúti konténeres, ömlesztett;

- R17 Közút: közúti konténeres, platós zárt jármün;

- R18 Vasút: vasúti konténeres, ömlesztett;

- R19 Közút: közúti zsákokba kiszerelve, rakodólapos zárt jármün;

- R20 Vasút: vasúti konténeres, ömlesztett;

- R21 Közút: közúti BIG-BAG zsákban raklapos, zárt jármün;

- R22 Vasút: vasúti konténeres, raklapos BIG-BAG zsákban, vasúti kocsin.

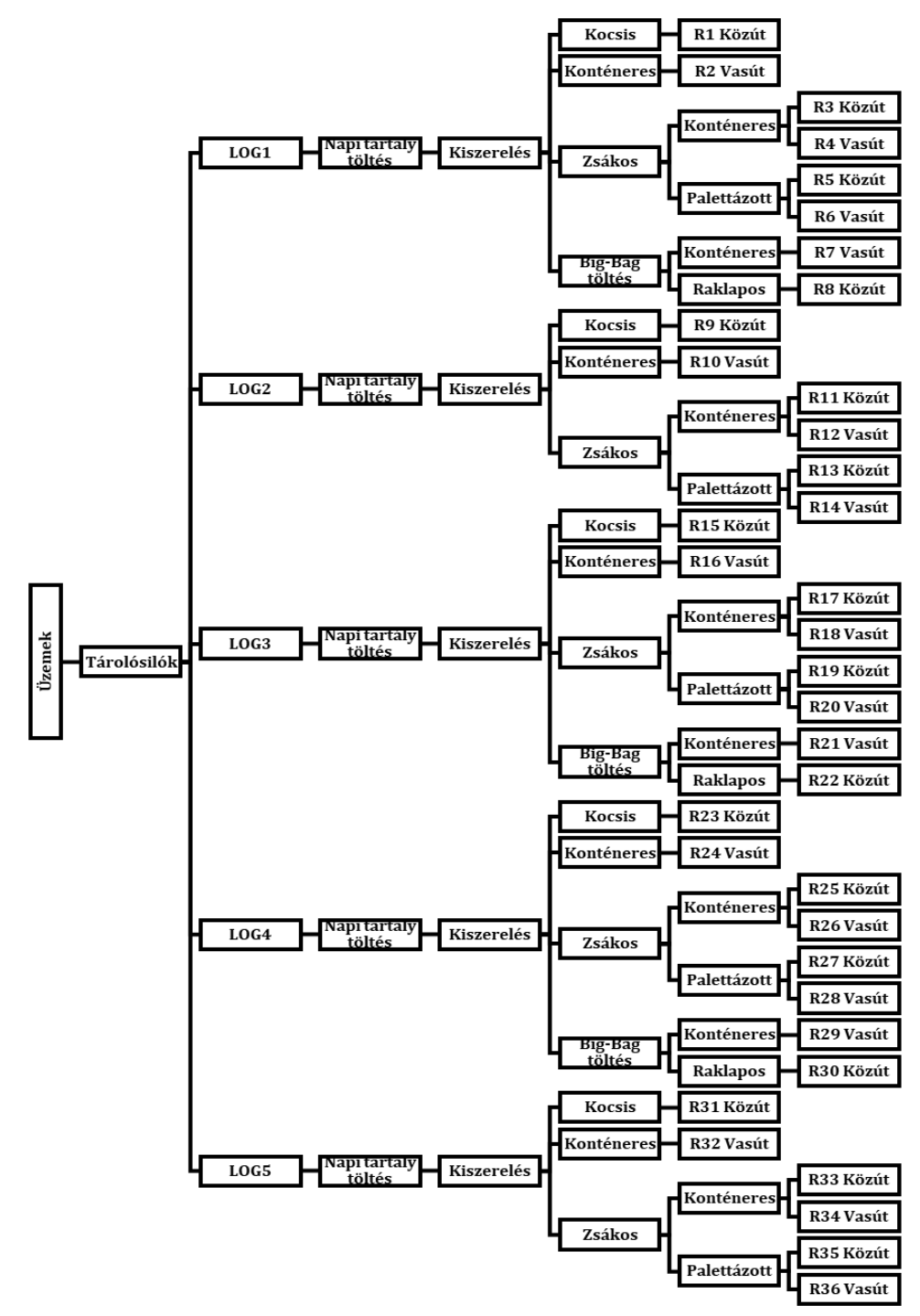

5. ábra. Bázisvállalat komplex modell rendszere (gyártás, kiszerelés és szállitás) 
LOG 4:

- R23 Közút: közúti tartálykocsitöltés, ömlesztett;

- R24 Vasút: vasúti konténeres, ömlesztett;

- R25 Közút: közúti konténeres, platós zárt jármün;

- R26 Vasút: vasúti konténeres, ömlesztett;

- R27 Közút: közúti zsákokba kiszerelve, rakodólapos zárt jármün;

- R28 Vasút: vasúti konténeres, ömlesztett;

- R29 Közút: közúti BIG-BAG zsákban raklapos, zárt jármün;

- R30 Vasút: vasúti konténeres, raklapos BIG-BAG zsákban, vasúti kocsin;

LOG5:

- R31 Közút: közúti tartálykocsitöltés, ömlesztett;

- R32 Vasút: vasúti konténeres, ömlesztett;

- R33 Közút: közúti konténeres, platós zárt jármün;

- R34 Vasút: vasúti konténeres, ömlesztett;

- R35 Közút: közúti zsákokba kiszerelve, rakodólapos zárt jármün;

- R36 Vasút: vasúti konténeres, ömlesztett.

A LOG egységek sajátosságait a következő táblázatban foglalom össze, hiszen a kiszállítás ütemezésénél több kiszerelési módozatot is figyelembe kell venni.

6. táblázat. Kiszolgáló üzemek kiszerelési kapacitásai [Saját szerkesztés]

\begin{tabular}{|c|c|c|c|c|c|}
\hline $\begin{array}{c}\text { Kiszolgáló } \\
\text { egységek }\end{array}$ & $\begin{array}{c}\text { Siló } \\
{[\mathbf{d b}]}\end{array}$ & $\begin{array}{c}\text { Kiszerelés/ } \\
\text { nap } \\
{[\mathbf{t}]}\end{array}$ & $\begin{array}{c}\text { Kocsis } \\
\text { töltési idő } \\
{[\text { [óra] }}\end{array}$ & $\begin{array}{c}\text { Kocsi töltés hatással } \\
\text { van-e a kiszerelésre }\end{array}$ & $\begin{array}{c}\text { Big-Bag } \\
\text { töltés } \\
\text { Igen/Nem }\end{array}$ \\
\hline LOG 1 & 17 & 240 & 1,5 & Igen & Igen \\
\hline LOG 2 & 50 & 540 & 0,7 & Nem & Nem \\
\hline LOG 3 & 29 & 480 & 1,7 & Igen & Igen \\
\hline LOG 4 & 37 & 660 & 0,8 & Nem & Igen \\
\hline LOG 5 & 11 & 240 & 2,1 & Igen & Nem \\
\hline
\end{tabular}

Ahogyan a 6. táblázat is reprezentálja, az egyes területi logisztikai üzemek eltérő kapacitásokkal rendelkeznek. Okai, a jelenlegi technológiai kialakításaira és jellegzetességeire vezethetők vissza. A kocsis töltések számát a helyi adottságok befolyásolják, emiatt a töltési időszükségletben kb. 1,5 óra differencia is elöfordulhat.

Végül elemeztem a beérkezett jármüvek számát egy adott időszakra történt kiszolgálás vonatkozásában - az $I D_{1}$-re. Az alábbi 7 ábrát értelmezve jól látható, hogy 21:00 óra után is történt jármü kiszolgálás. Ezt normál nyitvatartás mellett nem képes kiszolgálni, hiszen legalább 1,5 óra is lehet a kiszolgálás időtartama. Javaslatom az eltolt munkarend kialakítása lenne, így átfedéssel dolgoznának, és az átállás folyamata felgyorsulna, ezáltal csökkenne az időszakos feltorlódás. 


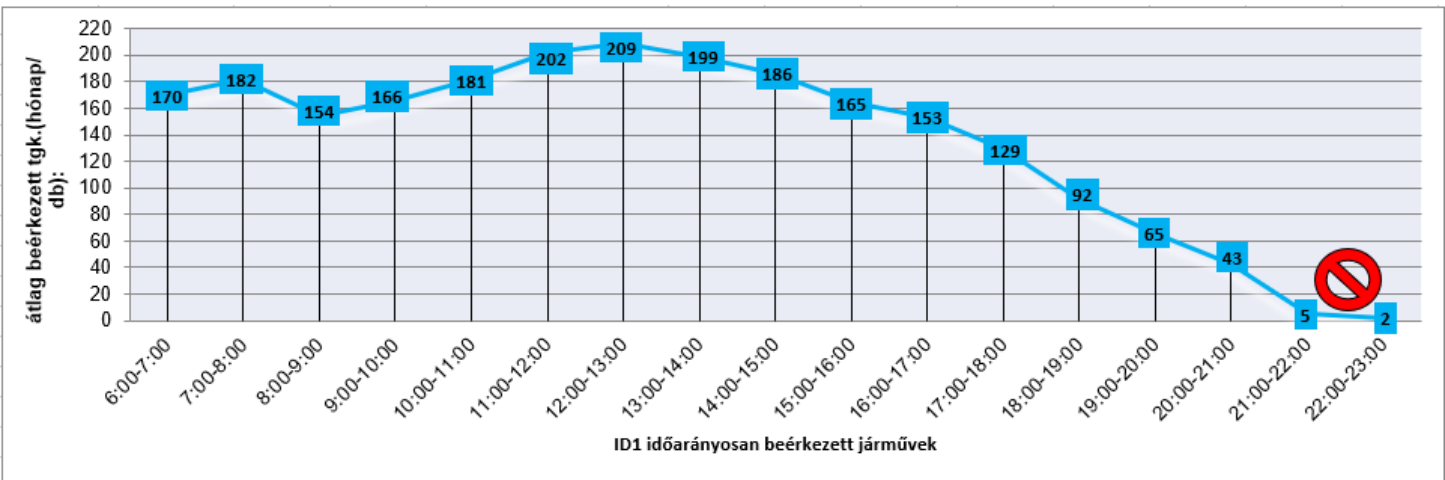

7. ábra. Adott idöszakra beérkezett átlag kiszolgált jármüvek száma - óránkénti bontásban

A LOG egységek integrált kiszállításához az alábbi döntéseket lehet értelmezni:

- Kiszállítási feladat definiálása (késztermék típusa, mennyisége, szállítási mód megválasztása).

- Kiszerelés módozatának megválasztása:

○ Silós-,

○ Kocsis-,

○ Zsákos-,

○ Big-bag töltés.

- Kiszerelés folyamata (honnan, mikor és hová kerüljön az ömlesztett anyagok töltésének végrehajtásra).

Az ütemezés feltételei, korlátai és célfüggvényei - a folyamatok ismeretében a következőek:

Szük keresztmetszetek - feltételek, korlátok bemutatása:

- LOG 2 silópark kezelése.

- Kiszerelési formák technológiai korlátai:

o Szállítási típus kiválasztása egyes kiszállítási feladatnál,

o Kiszerelési kapacitások helyi rendelkezésre állása és felhasználása: töltés, ürítés és egységrakományképzés,

○ Vevői igények kiszolgálásának sorrendje,

○ A döntés idejében a rendszer jelenlegi állapota.

- Kiszerelési folyamatok egyidejü alkalmazása az egyes LOG egységnél:

o Big-bag töltési lehetőségek,

○Zsákológépek eltérő kapacitásai,

○ Tartálykocsi töltési idők megoszlása.

- Gépjármúvek fogadásai.

Célfüggvények a következőek:

o Készletek minimális szintjén tartása,

○ Költségek minimalizálása,

o Megrendelések igényvezérelt teljesítése.

A kiszállítási feladatok tervezésénél az $\beta$-dik kiszállítási feladat kezdésének időpontja:

$$
T_{K \beta}=T_{X \beta}+\sum_{i=1}^{n} t_{T \beta i}^{R}[\text { óra] }
$$


ahol a $T_{X \beta}$ a $\beta$-dik kiszállítás, mely a kiszerelés kezdési időpontját adja meg. Ezt az időpontot a jármü rendelkezésre állásától értelmezzük.

A $\beta$-dik szállítási feladat, a R-edik kiszállítási módozatnál, a x-edik terméknél és az i-edik kiszerelési lépésnél.

ahol a

$$
t_{T \beta i}^{R \eta}=\frac{Q_{x}^{\eta}-Q_{T \beta i}^{R \eta}}{Q_{x}^{\eta}} t[o r a]
$$

$Q_{x}^{\eta}$ a -dik kiszerelés egységnyi termékének mennyisége [t],

$Q_{T \beta i}^{R \eta}$ a R-edik kiszállítási mód, ahol az x-edik késztermékből az i-edik lepésnél a $\beta$-dik szállítási feladathoz előkészített vevő általi termékmennyiség [t].

$$
\text { Ha } Q_{T \beta i}^{R \eta}>Q_{x}^{\eta}[t] \text {, akkor } t_{T \beta i}^{R \eta}=0
$$

A probléma célfüggvényei leírják a szállítási feladatok költségeinek minimalizálását, ami tulajdonképpen a legjobb ütemezési változat müködési költséget jelenti.

$$
K=K_{R}+K_{K}+K_{B}=\min [\text { egység] }
$$

ahol a költségfüggvények a következők:

1. a megrendelés, $K_{R}$ teljesítésének költsége - időfüggvényében (egy adott időszakra):

$$
K_{R}=k_{R 1} \sum_{\beta=1}^{n} \Delta t_{1 \beta}+k_{R x} \sum_{\beta=1}^{n} \Delta t_{x \beta}[\text { egység] }
$$

ahol:

a $k_{R 1}$ a rendelés fajlagos költségei,

$\mathrm{n}$ a vizsgált időszaki feladatok,

$\Delta t$ egyes feladatok igényelt időpontjai.

2. a készletek átlagos költsége: A különböző tárolási módozatokban a vizsgált ütemezési időpontban a készletek átlagos értékének megfelelö költségek. Ezen költségek a forgóeszközökből és a tárolókból határozhatóak meg.

$$
K_{K}=\left(\sum_{f=1}^{p} k_{s} C_{s}+\sum_{f=1}^{\varphi} k_{t} C_{t}+\ldots+\sum_{f=1}^{n} k_{x} C_{x}\right) I D_{1} \text { [egység] }
$$

ahol:

a $C_{s}, C_{t}, C_{x}$ a készlet értékek módozatonként,

a $k_{s}$ az $I D_{1}$ időegységnyi fajlagos költségek. 
3. gépjárművek fenntartási költségei: Ami a cégen belüli tartózkodást és a legyártott termékféleség szerinti költségeket jelenti, ami arányos a termelés, a kiszerelés és a szállítás ráfordított költségeivel.

$$
K_{B}=k_{j a ́}+k_{k t}[\text { egység] }
$$

ahol:

a $k$ já a jármü várakozási költségei,

a $k_{k t}$ a gyártott késztermékek eseti átadási költségei.

\section{Bázis vállalat vevőkiszolgálásának fejlesztése}

I. Fejlesztési javaslat: eltérö müszakrend kialakitása: A LOG2 egységnél megállapítható, hogy eltérő munkarendben dolgoznak. Ez azt jelenti, hogy 6:00-14:00, 14:00-22:00, és 22:00-6:00 óráig. Ennek oka főleg a gyártáshoz köthető, hiszen biztosítani kell a folyamatos anyagáramlást a termelő- és a logisztika egységei között.

II. Fejlesztési javaslat: technológiai átalakitás végrehajtása: A siló parkok vizsgálata során azt tapasztaltam, hogy a LOG4 egység silópark kezelése szemmel láthatóan érdekességet, hiszen egyedülálló az, hogy a kiszerelö üzemek közül csak itt történik silópark kezelése, minden más területi egység esetében a gyártó üzemek végzik. Megoldásom egy technológia átalakítás lenne, hogy a termelést végrehajtó üzemből történne a tároló silók töltése, hogy este ne kelljen személyzet a területre.

A bemutatott matematikai modell alapján kidolgozható a késztermékek kezelésének optimális ütemezési változata, mely adott időszak megrendelései alapján ütemezhetők:

- tárolósilók,

- napi tartályok,

- tárolók,

- egységrakományok,

- zsákok,

- gépjármúvek töltései.

A fentiek alkalmazásával optimális ütemezési program állítható össze, mely heurisztikus megoldás segítségével kiválasztható a leggazdaságosabb ütemezési változat.

\section{Esettanulmány}

A következő tanulmányban a fenti modellt alkalmazom, és egy gyakorlati példán keresztül mutatom be egy fiktív vállalat késztermék átszállítási munkálatainak gazdaságos ütemezését. A feladat megoldása lineáris programozási (LP) feladatként a Scilab rendszer alapján a Microsoft Solver program felhasználásával készült. A 8. táblázat tartalmazza, hogy a kiszolgáló területi logisztikai egységeknek (továbbiakban: LOG 1-4) 1644 [t] mennyi jármünyi készterméket kell átvennie a termelö üzemektől (továbbiakban: Üzem 1-3). A három üzem által gyártott késztermék mennyisége az alábbi egységek szerint oszlanak meg: 279; 967; 398 [t].

A négy LOG egység átvételi igénye a következö: 291; 277; 911; 165 [t]. Az üzemek és a LOG egyégek közötti szállítás 1 jármüre jutó költsége 1000 egység. Tehát úgy kell megoldani a késztermékek átvételét, hogy az összköltségük minimális legyen.

A 8. táblázat megoldása bizonyítja, hogy minden megrendelést (igényt) teljesíteni akarunk, így a készleteink felhasználásra kerülnek. Tehát a modellel kapott megoldás a leggazdaságosabb ütemezési 
változatot adja meg, amellyel lekezelhetők az üzemek által termelt és átadott késztermékek, ami jelenleg 248629 egységnyi összköltséget jelent.

8. táblázat. Napi késztermékek alapadatainak összeállitása [Saját szerkesztés]

\begin{tabular}{|l|c|c|c|c|c|}
\hline & LOG 1 & LOG 2 & LOG 3 & LOG 4 & Készlet (napi gyártás) [t] \\
\hline Üzem 1 & 204 & 31 & 34 & 10 & $\mathbf{2 7 9}$ \\
\hline Üzem 2 & 86 & 6 & 854 & 21 & $\mathbf{9 6 7}$ \\
\hline Üzem 3 & 1 & 240 & 23 & 134 & $\mathbf{3 9 8}$ \\
\hline $\begin{array}{l}\text { Késztermék átvé- } \\
\text { teli igény [t] }\end{array}$ & $\mathbf{2 9 1}$ & $\mathbf{2 7 7}$ & $\mathbf{9 1 1}$ & $\mathbf{1 6 5}$ & \\
\hline
\end{tabular}

9. táblázat. Napi késztermékek optimális kezelése [Saját szerkesztés]

\begin{tabular}{|l|c|c|c|c|c|}
\hline & LOG 1 & LOG 2 & LOG 3 & LOG 4 & Elszállított mennyiség [t] \\
\hline Üzem 1 & 0 & 0 & 279 & 0 & $\mathbf{2 7 9}$ \\
\hline Üzem 2 & 291 & 277 & 234 & 165 & $\mathbf{9 6 7}$ \\
\hline Üzem 3 & 0 & 0 & 398 & 0 & $\mathbf{3 9 8}$ \\
\hline Beérkezett mennyiség [t] & $\mathbf{2 9 1}$ & $\mathbf{2 7 7}$ & $\mathbf{9 1 1}$ & $\mathbf{1 6 5}$ & \\
\hline Összköltség: & 248629 & [egység] & & & \\
\hline
\end{tabular}

10. táblázat. Érzékenységvizsgálat jelentése [Saját szerkesztés]

\begin{tabular}{|l|c|c|c|c|c|}
\hline \multicolumn{7}{|l|}{ Változócellák } & $\begin{array}{c}\text { Végső } \\
\text { Érték }\end{array}$ & $\begin{array}{c}\text { Csökkentett } \\
\text { költség }\end{array}$ & $\begin{array}{c}\text { Célérték } \\
\text { együtthatója }\end{array}$ & $\begin{array}{c}\text { Megengedhető } \\
\text { Növelés }\end{array}$ & $\begin{array}{c}\text { Megengedhetö } \\
\text { Csökkentés }\end{array}$ \\
\hline Üzem 1 LOG 1 & 0 & 938 & 204 & $1 \mathrm{E}+30$ & 938 \\
\hline Üzem 1 LOG 2 & 0 & 845 & 31 & $1 \mathrm{E}+30$ & 845 \\
\hline Üzem 1 LOG 3 & 279 & 0 & 34 & 809 & $1 \mathrm{E}+30$ \\
\hline Üzem 1 LOG 4 & 0 & 809 & 10 & $1 \mathrm{E}+30$ & 809 \\
\hline Üzem 2 LOG 1 & 291 & 0 & 86 & 746 & $1 \mathrm{E}+30$ \\
\hline Üzem 2 LOG 2 & 277 & 0 & 6 & 845 & $1 \mathrm{E}+30$ \\
\hline Üzem 2 LOG 3 & 234 & 0 & 854 & $1 \mathrm{E}+30$ & 746 \\
\hline Üzem 2 LOG 4 & 165 & 0 & 21 & 809 & $1 \mathrm{E}+30$ \\
\hline Üzem 3 LOG 1 & 0 & 746 & 1 & $1 \mathrm{E}+30$ & 746 \\
\hline Üzem 3 LOG 2 & 0 & 1065 & 240 & $1 \mathrm{E}+30$ & 1065 \\
\hline Üzem 3 LOG 3 & 398 & 0 & 23 & 746 & $1 \mathrm{E}+30$ \\
\hline
\end{tabular}




\begin{tabular}{|l|c|c|c|c|c|}
\hline Üzem 3 LOG 4 & 0 & 944 & 134 & $1 \mathrm{E}+30$ & 944 \\
\hline \multicolumn{7}{|l|}{ Korlátozó feltételek } & $\begin{array}{c}\text { Végsó } \\
\text { Érték }\end{array}$ & $\begin{array}{c}\text { Árnyék- } \\
\text { ár }\end{array}$ & $\begin{array}{c}\text { Korlátozó } \\
\text { feltétel - jobb } \\
\text { oldal }\end{array}$ & $\begin{array}{c}\text { Megengedhetó } \\
\text { Növelés }\end{array}$ & $\begin{array}{c}\text { Megengedhetó } \\
\text { Csökkentés }\end{array}$ \\
\hline Név & 291 & 291 & 0 & 291 \\
\hline $\begin{array}{l}\text { Beérkezett meny- } \\
\text { nyiség LOG 1 }\end{array}$ & 291 & 277 & 0 & 277 \\
\hline $\begin{array}{l}\text { Beérkezett meny- } \\
\text { nyiség LOG 2 }\end{array}$ & 277 & 6 & 911 & 0 & 234 \\
\hline $\begin{array}{l}\text { Beérkezett meny- } \\
\text { nyiség LOG 3 }\end{array}$ & 911 & 854 & 165 & 0 & 165 \\
\hline $\begin{array}{l}\text { Beérkezett meny- } \\
\text { nyiség LOG 4 }\end{array}$ & 165 & 21 & 279 & 234 & 1 (E+30 \\
\hline $\begin{array}{l}\text { Üzem 1 Elszállí- } \\
\text { tott mennyiség }\end{array}$ & 279 & -820 & 967 & 0 & 0 \\
\hline $\begin{array}{l}\text { Üzem 2 Elszállí- } \\
\text { tott mennyiség }\end{array}$ & 967 & 0 & 398 & 234 & 0 \\
\hline $\begin{array}{l}\text { Üzem 3 Elszállí- } \\
\text { tott mennyiség }\end{array}$ & 398 & -831 & & & 0 \\
\hline
\end{tabular}

A célfüggvény érzékenységvizsgálatának eredményét a változó cellák tartalmazzák, a jobboldal érzékenységvizsgálatának eredménye a korlátozó feltételeknél kerül megjelenítésre. A megengedhető növelés és csökkenés értékei a célfüggvény együtthatói, illetve a jobboldal változásának mértékét jelenti. A $\infty$ jelölése $1 \mathrm{E}+30$ számértékkel történik. A csökkentett költség a megfelelö feltételek bal és jobboldala közötti különbséget adja meg. A vizsgálatok eredményeként levonható a következtetés: a LOG egységek arányának ideális megválasztása adott szállítástól függő. Tehát az érzékenységvizsgálattal megvizsgáltam, hogy a kapott összköltség, azaz a célcella mezőben megadott képlet, vagy a korlátozó feltételek változtatása esetén a megoldás mennyire érzékeny.

\section{5. Összefoglalás}

A termelés szorosan összekapcsolódik a LOG egységekkel. A logisztikai feladatot ellátó szolgáltató komplex anyagmozgatási, szállítási, tárolási és raktározási feladatokat lát el. Az alternatív megoldások keresése a jelenlegi konstrukció javításában rejlik.

A szük keresztmetszetek igazolják a kapacitások egyenlötlen kihasználását, hiszen a vevő kezelése akár kiszolgálási időn túl is történhet.

Továbblépési lehetőség a gépjárműfogadásának elemzése, hiszen a töltő tevékenység is kiemelt terület. Úgy gondolom, hogy a munkarend átalakítása lehetővé tenné a hatékonyabb vevőkiszolgálást a csúcsidőben beérkezett jármüvek esetén.

Meggyőződésem, hogy a jelenlegi technológiák fentarthatóbb üzemeltetésével jelentős eredmények érhetők el a fejlesztések révén. A folyamatos technikai fejlődés meghatározó marad a cégek számára. 


\section{Köszönetnyilvánítás}

A cikkben ismertetett kutató munka az EFOP-3.6.1-16-2016-00011 jelü „Fiatalodó és Megújuló Egyetem - Innovatív Tudásváros - a Miskolci Egyetem intelligens szakosodást szolgáló intézményi fejlesztése" projekt részeként - a Széchenyi 2020 keretében - az Európai Unió támogatásával, az Európai Szociális Alap társfinanszírozásával valósul meg.

\section{Irodalom}

[1] Cselényi J., Illés B. (szerk.): Logisztikai rendszerek I., Miskolci Egyetem, 2004.

[2] Karácsonyi Péter: Üzemszervezés, http://www.tankonyvtar.hu/hu/tartalom/tamop412A/20100019_Uzemszervezes/ch13.html

[3] Dömötörfi, Á.: Paradigmaváltás a logisztikában, In: Tamás, P. (szerk.) Innováció és fenntartható felszíni közlekedés: IFFK-Konferencia, Budapest, Magyarország: Magyar Mérnökakadémia (MMA), (2013) pp. 86-95. Paper: Paper 17, 10 p, 2013. ISBN 978-963-88875-3-5

[4] Hsiao, H. I., Kemp, R. G. M., van der Vorst, J. G. A. J., (Onno) Omta, S. W. F.: A classification of logistic outsourcing levels and their impact on service performance: Evidence from the food processing industry, International Journal of Production Economics, Volume 124, Issue 1, (2010) pp. 75-86. https://doi.org/10.1016/j.ijpe.2009.09.010

[5] Mentzer, J. T., DeWitt, W., Min, S.: Defining supply chain management, Journal Of Business Logistics, Volume 22, Issue 2, (2001) pp. 1-25. https://doi.org/10.1002/j.2158-1592.2001.tb00001.x

[6] https://www.cadenadesuministro.es/wp-content/uploads/2015/05/Collaborative-Outsourcing-IsLogistics-Outsourcing-Right-for-Your-Company-CH-Robinson.pdf, Utoljára megtekintve: 2020.07.22.

[7] Boysen, N., Schwerdfeger, S., Weidinger, F.: Scheduling last-mile deliveries with truck-based autonomous robots, European Journal of Operational Research, 271 (3), (2018) pp. 1085-1099. https://doi.org/10.1016/j.ejor.2018.05.058

[8] Yang, F., Dai, Y., Ma, Z-J.: A cooperative rich vehicle routing problem in the last-mile logistics industry in rural areas, Transportation Research Part E: Logistics and Transportation Review, Volume 141, 2020. https://doi.org/10.1016/j.tre.2020.102024

[9] Yang, F., Dai, Y., Ma, Z-J.: A cooperative rich vehicle routing problem in the last-mile logistics industry in rural areas, Transportation Research Part E, 141,102024, 2020. https://doi.org/10.1016/j.tre.2020.102024

[10] Zhang, Y., Shi, L., Chen, J., Li, X.: Analysis of an automated vehicle routing problem in logistics considering path interruption, Journal of Advanced Transportation, vol. 2017, Article ID 1624328, 10 pages, 2017. https://doi.org/10.1155/2017/1624328 